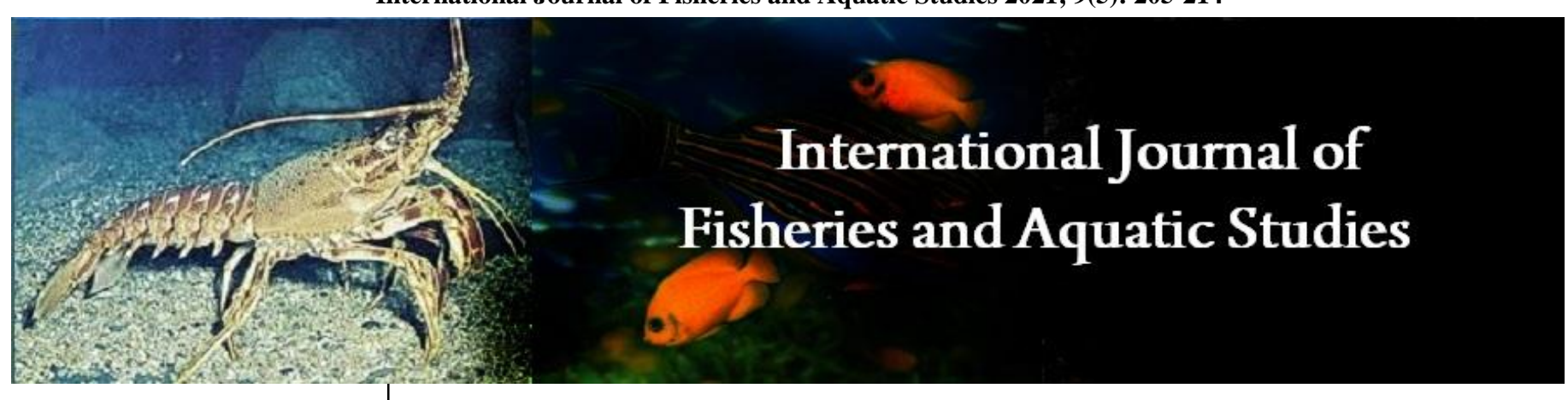

E-ISSN: 2347-5129

P-ISSN: 2394-0506

(ICV-Poland) Impact Value: 5.62

(GIF) Impact Factor: 0.549

IJFAS 2021; 9(5): 205-214

(C) 2021 IJFAS

www.fisheriesjournal.com

Received: 04-07-2021

Accepted: 06-08-2021

Madhu Sharma

Department of Fisheries,

COVAS, CSKHPKV, Palampur,

Himachal Pradesh, India

\section{Pooja Chadha}

Department of Zoology, GNDU,

Amritsar, Punjab, India

\section{Radhika Sharma}

Department of Biology and

Environment Sciences, COBS,

CSKHPKV, Palampur,

Himachal Pradesh, India

\section{Environmental biomonitoring using different biomarkers and their contribution in aquatic environmental research}

\author{
Madhu Sharma, Pooja Chadha and Radhika Sharma
}

DOI: https://doi.org/10.22271/fish.2021.v9.i5c.2570

\begin{abstract}
In an era where innumerable biological and synthetic compounds are perpetually introduced into the market every day in various forms, such as pharmaceuticals, cosmetics, nutraceuticals, fertilizers, pesticides, and nanoparticles, to serve multiple purposes, there is a need to develop rapid screening methods to evaluate their biosafety. Wide array of biomarkers used to demonstrate exposure to and effect of environmental contamination. In order to assess exposure to or effect of environmental pollutant on aquatic environment the following suite of fish biomarkers may be examined, oxidative stress parameters, hematological parameters, immunological parameters, genotoxic parameters and histology. The text explores the latest knowledge and thinking on these very important approaches for the assessment of environmental health, management and conservation. This review focuses on measurement of the genotoxic potential of chemicals in aquatic organism at different level of biological organization under field and laboratory conditions by using comet assay, micronucleus assay, polychromatic erythrocyte count.
\end{abstract}

Keywords: biomonitoring, comet assay, micronucleus assay, repair, polychromatic erythrocyte frequency, normochmatic erythrocyte frequency

\section{Introduction}

Human and other animals are exposed to a variety of contaminants that are present in the environment due to anthropogenic activities. Contaminants can be incorporated in the organism via different routes and get bioaccumulated in different tissues and can induce variation in cellular or biochemical components, processes, structures or functions. To assess the quality and health of an environment, use of a biological community is called as environmental biomonitoring which can clearly reveal early responses to environmental stress. Numbers of biomarkers are used in a routine biomonitoring program of aquatic environment in order to evaluate the pollutant induced stress syndrome. These include behavioral response, genotoxicity (comet assay, MN assay, sister chromatid exchange (SCE), chromosomal aberrations, polychromatic erythrocyte frequency), hematology and histopathological alterations. Fish respond to toxic agents similar to higher vertebrates and can allow the assessment of substances that are potentially hazardous to humans. Anthropogenic activities such as industrial, agricultural, domestic and urban lead to accumulation of toxicants in water bodies. These genotoxins are capable of damaging the DNA and show the irreversible effect. The importance of detection of genotoxic risk associated with polluted water along with the importance of comet assay and a micronucleus assay in environmental health assessment was given by Osman, (2014) ${ }^{[69]}$. This section includes the detailed review of literature highlighting the important studies using the biomarkers like micronucleus assay, comet assay and polychromatic erythrocyte frequency to study the effect of different xenobiotics. A detailed study was conducted on the relevance of genotoxicity tests in aquatic environment research.

\section{Micronucleus Assay}

Schroedter, (1966) ${ }^{[78]}$ discovered micronuclei in bone marrow after treatment with enzymes. The method has been developed and expanded to a wide range of genotoxicity testing. Schmid, (1976) ${ }^{[80]}$ used micronuclei as a parameter for the first time.
Madhu Sharma

Department of Fisheries, COVAS, CSKHPKV, Palampur,

Himachal Pradesh, India 
The micronuclei test (MNT) has been widely used as a fast method of testing genotoxic agents in various mammalian models (Sehgal et al., 2011 and Garg et al., 2008) ${ }^{[38] .}$ Micronucleus test has been used by a number of researchers for assessing the genetic damage (Ansari et al., 2011; Galindo et al., 2014; Kumar et al., 2013; Nwani et al., 2011) [13, 37, 50, ${ }^{66]}$. Several scientists have also identified other nuclear abnormalities, including nuclear bud, fragmented nucleus, vacuolated nucleus and binucleated cells as an indicator of genotoxicity (Ayllon and Garcia-Vazquez, 2000; Cavas and Ergene-Gozukara, 2003; Cavas et al., 2005; Muranli and Guner, 2011; Talapatra and Banerjee, 2007) ${ }^{[28,18,30,59,88,95] .}$ Ayllon and Garcia-Vazquez, (2000) [18] compared the sensitivity of two fish species European minnow (Phoxinus phoxinus) and Mollei (Poecilia latipinna) using the micronucleus assay. Cyclophosphamide (40 $\mathrm{mg} / \mathrm{kg})$ or mitomycin C (20 mg/kg) was injected to fish intraperitoneally for 24 hours. Various nuclear abnormalities were observed along with micronuclei. A further comparison of sensitivity between 3 fish species Tilapia rendalli, $O$. niloticus and $C$. carpio by using the micronucleus assay was done by Grisolia and Starling, (2001) ${ }^{[39]}$. Waste water from two municipal treatment plants that empty into Lake Paranoa were tested for micronucleus induction. T. rendalli was found to be the most sensitive species and $C$. carpio as the most resistant one. Comparisons between the micronuclei induction in fish and mouse was done after treatment with cyclophosphamide, mitomycin $\mathrm{C}$ along with other pesticides (Decis $25 \mathrm{CE}$ and kelthane $480 \mathrm{CE}$ ). Fish, T. rendalli was used and results indicated that both cyclophosphamide and mitomycin $\mathrm{C}$ induced $\mathrm{MN}$ in both the test organisms. Decis $25 \mathrm{CE}$ and Kelthane $480 \mathrm{CE}$ increased $\mathrm{MN}$ frequency in $T$. rendalli at doses 1.0 and $5.0 \mathrm{mg} / \mathrm{kg}$ (Grisolia, 2002) ${ }^{[40]}$.

Textile mill effluent was tested by Cavas and ErgeneGozukara, (2003) ${ }^{[28]}$ for its cytogenotoxic effects on a fish $O$. niloticus by using micronuclei test and analyzing nucleolar organizer region. Dose dependent increase in the frequencies of micronucleated and other NA in erythrocytes were observed while interphase AgNOR frequency in fin cells decreased after 90 and 180 minutes of exposure of textile mill effluent. Cavas and Ergene-Gozukara, (2005a) ${ }^{[30]}$ detected the genotoxic effects of effluents from petroleum refinery and a chromium processing plant. Micronucleus analysis was carried out in gill epithelial cells and peripheral blood erythrocytes and the study showed that both the effluents had genotoxic potential. However, petroleum refinery effluent induced high levels of genetic damage than of chromium processing plant effluent. Koca et al. (2005) ${ }^{[49]}$ studied water quality and distribution of some heavy metals in three different organs of Lipomis gibbosus from Cine stream (Turkey). Micronucleus formation was studied in erythrocytes from peripheral blood and higher $\mathrm{MN}$ frequency in fish caught from the Cine stream was found as compared to control. Zn was found as most accumulated metal in tissue as well as water. In gill tissue primary and secondary gill lamellae got degenerated. Peripheral blood and cephalic kidney of Turbot (S. maximus) and Atlantic cod (G. morua) were used for testing the genotoxicity caused by crude oil using the micronucleus assay (Bar`sien'e et al., 2006) [21]. Blood cells and kidney cells were found to have significantly higher micronucleated cells when treated with $30 \mathrm{ppb}$ of nonylphenol, $0.5 \mathrm{ppm}$ of oil along with alkylphenol and PAH. Group treated with nonylphenol showed fragmented apoptotic cells and significant intertissue differences. MN and nuclear abnormalities in gill and kidney erythrocytes of fish L. bata grown in sewage fed fish farm of east Calcutta wetlands was tested by Talapatra and Banerjee, (2007) ${ }^{[88]}$. Kidney tissue showed an increased value of $\mathrm{MN}$ as compared to gill without any statistical difference, but both the tissues showed statistical higher MN and NA as compared to control. Arslan et al. (2010) ${ }^{[14]}$ detected micronucleus frequency in aquatic organisms for monitoring pollution of Izmui Bay (Western Turkey), on erythrocytes and gills of mussels (Mytilus galloprovinciali) and highest frequency of $\mathrm{BN}$ and $\mathrm{MN}$ was found in the gill tissue, suggesting the gill tissue as a better marker in micronuclei test. Ayoola et al. (2012) [15] investigated the genotoxicity of textile effluent discharge, using micronuclei assay. It was found that textile effluent increased the cytogenetic damage and the chemicals present in the effluent were found to be bioaccumulated and biomagnified in aquatic organisms hence affecting man. A case study in the Abu-rawash area (Egypt) was performed by Lasheen et al. (2012) ${ }^{[52]}$. The toxicity of wastewater effluent on African catfish (C. garipinus and O. niloticus) was carried out. Along with this, heavy metals (lead, Zinc, copper and cadmium) were also estimated in some tissues of these fishes. Lead and Cadmium metal concentrations were found to be above the permissible level and micronucleus test showed the genotoxic effect of waste water effluent on fish. Kaur et al. (2013) [47] evaluated the genotoxicity of dyeing industry effluent in $C$. mrigala by using micronucleus assay. Three sublethal concentrations $24.48 \%, 12.24 \%$ and $6.12 \%$ were used for 96 hours of exposure. Blood cells from kidney were used and the maximum effect was observed at $24.48 \%$ concentration after 96 hours of exposure. Melo et al. (2013) [56] found the usefulness of the micronucleus assay for genotoxic biomonitoring and compared the frequencies of micronucleated erythrocytes and nuclear abnormalities among different species of the electric fish of order Gymntifomes collected from localities of Eastern Amazon. Only one sample collected from the impacted site in the River Caripetuba showed a significant number of NAs which was due to waste water from neighboring mining industries and by burnt fuel released by the local community.

Omar et al. (2012) ${ }^{[68]}$ found that high concentrations of heavy metals have a potential genotoxic effects and genotoxicity is possibly related to agricultural and domestic activities. The two species of fish were used $O$. nilotics and Mugil cephalus. Both the species collected from the polluted area getting agricultural sewage and domestic non treated discharge and showed a significantly higher $\mathrm{MN}$ and NA frequencies as compared to control. Galindo et al. (2014) [37] tested genotoxicity of metals in fish Bathygobius soporato using micronucleus assay. Erythrocytes were used for testing and samples for testing were taken from tide pools of Salvador city of Brazil. Elevated level of micronucleated cells were observed in the erythrocytes as compared to the control.

Evaluation of the genotoxicity due to heavy metals on the three fish species, i.e. Common carp (C. carpio), Prussian carp (Carassius gibelio) and Peppered cory (Corydoras paleatus) was done. Fish were given 21 days exposure to cadmium $(0.005-0.1 \mathrm{mg} / \mathrm{l})$ and copper $(0.01-0.25 \mathrm{mg} / \mathrm{l})$. Induction of micronuclei and binucleated cells were evaluated in erythrocytes, gill epithelial cells and liver cells. The results suggested the gill and liver to be more sensitive sites as compare to the erythrocytes (Cavas et al., 2005) ${ }^{[30]}$. Yadav and Trivedi, (2009) ${ }^{[99]}$ evaluated the toxicity of three heavy metals, present in Agro-industrial effluent viz arsenic, 
mercury and copper using micronuclei assay in fish $C$. punctatus. Fish were exposed to sublethal concentrations, i.e. $10 \%$ of 96 hours $\mathrm{LC}_{50}$ of heavy metal compounds $\mathrm{HgCl}_{2}$ $(0.081 \mathrm{mg} / \mathrm{l}), \mathrm{As}_{2} \mathrm{O}_{3}(6.936 \mathrm{mg} / \mathrm{l})$ and $\mathrm{CuSO}_{4} .5 \mathrm{H}_{2} \mathrm{O}(0.407 \mathrm{mg} / \mathrm{l})$ for 24, 48, 72, 96 and 168 hours. A significant increase in MN frequency in fish exposed to metal compound was observed and the highest effect of As followed by $\mathrm{Hg}$ and least of $\mathrm{Cu}$ has been ascertained. Similarly Nagarani et al. (2009) [60] assessed the genotoxicity of mercuric chloride in marine fish Therapon jarbua. Fish were exposed for 96 hours and significant increase in MN frequency was observed. Highest effect was seen after treatment with $0.25 \mathrm{ppm}$ of mercuric chloride. Choudhary et al. (2012) ${ }^{[31]}$ detected the genotoxic potential of lead nitrate on fish, $C$. punctatus by assessing the mitotic index in kidney cells and micronucleated erythrocytes in the peripheral blood. The mitotic index decreased with increase in concentration, whereas micronucleated erythrocytes increased with an increase in the concentration and duration of exposure. Talapatra et al. (2014) ${ }^{[89]}$ tested three concentrations of zinc $(5,10$ and $30 \mathrm{ppm})$ on fish $H$. fossilis for micronucleus induction. Treatment was given for 24, 48, 72 and 96 hours and time and dose dependent increase in $\mathrm{MN}$ induction was observed.

Spleen and peripheral blood erythrocytes of fish Fathered minnow were tested for micronuclei induction in response to mitomycin c and cyclophosphamide. Maximum tolerant dose by injecting mitomycin $\mathrm{c}$ and cyclophosphamide was found to be 10 and $400 \mathrm{mg} / \mathrm{kg}$ respectively. Induction of micronucleus was studied after 1, 2, 4, 8 and 14 days. Significant induction of micronuclei was observed in erythrocytes from spleen, but not from peripheral blood after 8 and 14 days in mitomycin exposed groups. But $400 \mathrm{mg} / \mathrm{kg}$ cyclophosphamide failed to significantly induce micronuclei in erythrocytes from any tissue (Winter et al., 2007) ${ }^{[97]}$. Ali et al. (2008) ${ }^{[7,9]}$ reported the gill cells to be more sensitive as compared to kidney tissue and lymphocytes. Fish, $C$. punctatus was exposed to monocrotophos, commonly known as azodrin, one of the organo phosphate pesticides. Gill showed the highest induction of micronuclei. Similarly Sharma and Chadha, (2016) ${ }^{[83]}$ also found gill as most sensitive tissue when tested blood cells from peripheral circulation and blood cells from gill and kidney tissue in fish $C$. punctatus when treated with 4-nonylphenol.

Abdul-Farah et al. (2003) [3] had evaluated the genotoxic effects of pentachlorophenol (PCP) and 2, 4dichlorophenoxyacetic acid (2, 4-D) on fish $C$. punctatus. Sublethal treatment of both the chemicals was given for 96 hours of exposure. Time and dose dependent increase in MN frequency was found in both the groups. PCP was found to be more genotoxic as compared to 2, 4-D in term of $\mathrm{MN}$ induction in fish $C$. punctatus. Deltamethrin, class of pyrethroid insecticide significantly induced $\mathrm{MN}$ and NAs accompanied by increased lipid peroxidation when fish, $C$. punctatus was exposed to three concentrations $(0.4,0.8$ and $1.2 \mu \mathrm{g} / \mathrm{l}$ ) for 48 and 72 hours (Ansari et al., 2009) ${ }^{[13]}$. Ansari et al. (2011) ${ }^{[11]}$ evaluated the cytogenetic and oxidative stress caused by cypermethrin in fish $C$. punctatus. Chromosomal aberration (CA) and micronucleus (MN) tests were used to study the cytogenetic effects. CA and $\mathrm{MN}$ were found to show an increase in concentration dependent manner. Similarly, increased oxidative stress was also observed Sharma et al., 2021. Srivastava and Singh, (2015) ${ }^{[85]}$ used micronuclei as biomarker for testing genotoxicity of fungicide propiconazole (1.11 and $2.23 \mathrm{mg} / \mathrm{l})$ in fish $C$. batrachus.
Peripheral blood was used for micronucleus and binucleus induction and significantly higher values were observed in all the treatments as compared to control (Sharma et al., 2020).

\section{Polychromatic erythrocyte frequency}

Erythropoeitic toxicity evaluation is an important component for testing the safety level of environmental chemicals, and for erythropoiesis monitoring most popular and convenient method is PCEs count. Fish tends to maintain constant concentration of RBCs under normal conditions. The continuous entry of the new RBCs in the circulation and the destruction of old erythrocytes at the same rate occur, maintaining the dynamic equilibrium between erythropoiesis and destruction of RBCs (Randalli and Farrell, 1992) ${ }^{[75]}$. The toxicity of a substance can be assessed by PCE/NCE ratio because the toxicant can affect the division and maturation of erythropoietic cells. Decrease in the proportion of PCE/NCE is considered as indicator of mutagen-induced cytotoxicity

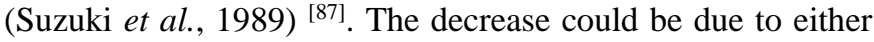
direct cytotoxicity or heavy DNA damage leading to cell death or apoptosis. The cytotoxic effect may be ascribable by the direct effect of chemical which may lead to chromosomal breakage as well as destruction of genetic material. These changes in cell may lead to cell death which may result in a reduction of PCE (Suzuki et al., 1989) ${ }^{[87]}$. Along with MN and NA, the ratio of polychromatic erythrocytes to normochromatic erythrocytes is also used for determining the cytotoxicity (Muranli and Guner, 2011) ${ }^{[59]}$. PCEs count in peripheral blood is one of the promising and convenient methods. The ratio between the two kinds of red blood cells i.e. polychromatic and normochromatic erythrocytes is a useful index to assess cytotoxicity (Udroiu, 2006) ${ }^{[93]}$.

Meier et al. (2002) ${ }^{[55]}$ assessed the genetic damage in fish using micronucleus (\% polychromatic erythrocytes and $\mathrm{MN}$ ) and comet assay in laboratory, watersheds and mesocosm. In laboratory 5 model genotoxic agents were tested on bluegill sunfish while in mesocosm caged common carp was exposed for 60 days to alachlor, atrazine, or benzo (a) pyrene. Two watersheds were selected one dominated with urban waste and other with agricultural wastes. All the tested groups showed the significant variation as compared to control. Pacheco and Santos, (2002) ${ }^{[71]}$ exposed fish Angullia angullia with benzopyrene and dehyroabietic acid for 180 days. Immature erythrocyte (IE) frequency was determined. A significant decrease in IE frequency was noticed after 30 days of exposure with benzopyrene and after 180 days when treated with dehydroabietic acid. Cavas, (2008) ${ }^{[27]}$ revealed the genotoxicity and cytotoxicity of mercury chloride (MC) and lead acetate (LA). $1 \mu \mathrm{g} /, \quad 5 \mu \mathrm{g} / \mathrm{L}$ and $10 \mu \mathrm{g} / \mathrm{L}$ concentrations of $\mathrm{MC}$ and $10 \mu \mathrm{g} / \mathrm{L}, 50 \mu \mathrm{g} / \mathrm{L}$ and $100 \mu \mathrm{g} / \mathrm{L}$ concentrations of LA were used. MN frequency was detected in gill tissue, fin epithelial cells and erythrocytes. Along with this PCE/NCE was also estimated in peripheral blood. Gill showed the highest sensitivity having highest $\mathrm{MN}$ frequency. While PCE/NCE ratio was found to decrease as compared to control after both the treatments, showing genotoxic as well as the cytotoxic effect of MC and LA. Muranli and Guner, (2011) ${ }^{[59]}$ studied the induction of micronuclei and nuclear abnormalities in Mosquito fish (Gambusia affinis) using erythrocytes. Three sublethal concentrations of LambdaCyhalothrin (LCT) tested were $1 \times 10^{-4} \mu \mathrm{g} / 1,2 \times 10^{-4} \mu \mathrm{g} / 1$ and $4 \times 10^{-4} \mu \mathrm{g} / \mathrm{l}$ for a period of $6,12,24$ and $48 \mathrm{~h}$. MN, NA and ratio of PCE/NCE was found to decrease after 24 and 48 hour treatment, indicating genotoxic and cytotoxic effect of 
lambda-cyhalothrin. Jerbi et al. (2011) [46] conducted an experiment to test the genotoxic and cytotoxic effect of formaldehyde and oxytetracycline. Micronucleus assay and $\mathrm{PCE} / \mathrm{NCE}$ were used for testing genocytotoxicity. Both the tested compounds showed genotoxicity and cytotoxicity, which increased in a time dependent manner. Pesticide pollution has also been studied using the micronucleus assay by Candioti et al. (2010) ${ }^{[26]}$. Evaluation of the genotoxicity and cytotoxicity of the pirimicarb carbanate (insecticide) on Cnesterodon decemmaculatus was done after acute exposure. Treatment with 50-100 $\mathrm{mg} / \mathrm{L}$ concentrations showed an increase in $\mathrm{MN}$ frequency. Circulating erythrocytes decreased in proportion and erythrocytes get increased which indicated cellular cytotoxicity. Cavas and Ergene-Gozukara, (2005b) [30]. found metronidazole (antibiotic-antiparasitic) to be genotoxic and cytotoxic to fish of $O$. niloticus. Fish were exposed to 5, 10, $15 \mathrm{mg} / \mathrm{L}$ concentrations for 24, 48, 72 hours. Micronucleated polychromatic and micronucleated normochromatic erythrocytes were counted and ratio of PCE/NCE was also calculated. Time and dose dependent increase in micronucleated cells were observed while the ratio of PCE and NCE was found to decrease. Sharma et al., 2014 ${ }^{\text {[84] }}$ observed decrease in PCE frequency in $C$. punctatus after acute and sub chronic exposure to 4-nonylphenol.

\section{Comet assay}

Since the introduction of the alkaline $(\mathrm{pH}-13)$ Comet assay in 1988, the breadth of applications and the number of investigators using this technique have increased almost exponentially. Olive and Banath, (2006) ${ }^{[67]}$ gave a protocol for comet assay, which could be completed in 24 hours and damage in individual eukaryotic cells could be determined. A large number of studies have been reported that comet assay is more sensitive as compared to the other genotoxic biomarkers (Frenzilli et al., 2004) ${ }^{[36]}$. The simplicity and sensitivity of comet assay made it an adequate test system for biomonitoring of even chronic level exposure (Belpaeme et al., 1996) ${ }^{[20]}$. Mitchelmore and Chipman, (1998) ${ }^{[57]}$ tested the sensitivity of comet assay for environmental monitoring. Trout fish has been used for the study and effect of benzopyrene was tested using four parameters (tail length, tail intensity, tail moment and percent head DNA) and it was concluded that the comet assay is a rapid, easy and sensitive technique. Sunjog et al. (2012) ${ }^{[82]}$ tested blood, gill and liver tissue to test DNA damage using the comet assay. Fish samples were taken from Zlatar reservoir as control site and Pestan and Bljanica rivers as polluted sites at Kolubara basin. They suggested tail moment as the most relevant measure for DNA damage. Dose dependent responses were observed in all the tissues. Different workers have used different tissues for the genotoxicity assessment of different chemicals by comet assay. Andrade et al. (2004) ${ }^{[11]}$ detected time and dose dependent increase in DNA damage in the erythrocytes of fish Mugil sp. after exposure to methyl methanesulphonate (MMS).

Ateeq et al. (2005) ${ }^{[15]}$ revealed the genotoxic effect of 2, 4dichlorophenoxyacetic acid and butachlor on erythrocytes of C. batrachus by using the comet assay. Tail length was used as a measure of DNA damage and highest damage at highest concentration and highest duration of exposure was observed. Woo et al. (2006) ${ }^{[98]}$ tested the genotoxicity in blood cells of Paralichthys olivaceus after exposure to polycyclic aromatic hydrocarbon. The degree of damage was found to increase with an increase in the concentration of PAH and highest damage was found at the station where PAH concentration was found to be maximum. Simoniello et al. (2009) ${ }^{[79]}$ used $0.300,0.150,0.075$ and $0.000 \mathrm{mg} / \mathrm{L}$ concentrations of cypermethrin and tested a neotropical fish Prochilodus lineatus for genotoxicity using the comet assay. The significantly higher DNA damage was observed after treatment with all the concentrations. Pandey et al. (2011) ${ }^{\text {[73] }}$ detected the genotoxic effect of profenofos on fish $C$. punctatus using single cell gel electrophoresis. Gill tissue showed a concentration dependent increase in the DNA damage when exposed with sublethal concentrations (0.58ppb, $1.16 \mathrm{ppb}$ and $1.47 \mathrm{ppb}$ ) for a period of $24,48,72$ and 96 hours. Guilherme et al. (2012) ${ }^{[42]}$ assessed the differential genotoxicity of herbicide Roundup ${ }^{\circledR}$ and its constituent's in fish $A$. anguilla. The fish was treated to Roundup ${ }^{\circledR}\left(58,116 \mu \mathrm{gL}^{-1}\right)$ glycophosate $\left(17.9,35.7 \mu \mathrm{gL}^{-1}\right)$ and polyethoxylated amine $\left(9.3,18.6 \mu \mathrm{gL}^{-1}\right)$. Blood cells were used for comet analysis and it was observed that both components contributed to the genotoxicity of the herbicide. Nwani et al. (2013) ${ }^{[65]}$ assessed the genotoxic effect and oxidative stress in $C$. punctatus after exposure with glyphosate based herbicide. Three sub lethal concentrations $3.25 \mathrm{mg} / \mathrm{l}, 4.07 \mathrm{mg} / \mathrm{l}$ and $6.51 \mathrm{mg} / \mathrm{l}$ were used for $1,7,14,21$, 28 and 35 days for genotoxicity testing using the comet assay. Highest genotoxicity was observed at $14^{\text {th }}$ day followed by a gradual decline. Nan et al. (2013) [63] assessed the genotoxicity and oxidative stress induced by 1-methyl-3octylimidazolium chloride in fish Misgurnus anguilliicadatus using liver cells. It was found that acute toxicity of 1-methyl3-octylimidazolium chloride above $20 \mathrm{mg} / \mathrm{l}$ induced significant induction of genotoxictiy as shown by the increased value of tail length and tail moment in concentration and time dependent manner. Ismail et al. (2014) [44] determined the genotoxicity in fish L. rohita after exposure to chlorpyrifos. Gill and blood cells were tested and time and dose dependent increase in the DNA damage was found. Gill was suggested as sensitive tissue as compared to blood cells. Javed et al., (2016) ${ }^{[45]}$ found that thermal power plant effluent leads to concomitant damage to DNA in gill and liver of fish $C$. punctatus. Significantly higher mean tail length was observed in exposed group compered to fish in the reference group.

Ternjej et al. (2010) ${ }^{[92]}$ tested the impact of aluminum (Al) contamination on DNA integrity in erythrocytes of Mosquito fish Gambusia holbrooki. This fish inhabited Lake Njivice (Island of Krk, Croatia) and a comparison was done with the same fish inhabiting the unpolluted Lake Ponikve. Three parameters tail length, tail intensity and tail moment were studied. Fish from Lake Njivice showed loss of genome integrity as compared to the fish from Lake Ponikve. Osterauer et al. (2011) ${ }^{[70]}$ surveyed the continual entering of platinum into the aquatic environment by road runoff and hospital sewage and raised the concern about its toxicity to organisms. Genotoxicity of platinum was tested at $0,0.1,1$, 10, 50, 100 and $200 \mu \mathrm{g} / \mathrm{l}$ in Zebrafish (D. rerio) and Ramshore snail (Marisa cornuarietis) using the single gel electrophoresis. The elevated level of DNA damage was observed in $M$. cornuarietis at $1 \mu \mathrm{g} / \mathrm{l}$ and beyond. Ahmed et al. $(2011)^{[4]}$ found highest damage in liver tissue followed by kidney and gill tissue when fresh water fish Climbing perch Anabas testudinus was tested with lead chloride. Ahmed et al. (2012) ${ }^{[5]}$ measured the genotoxic potential of Cadmium in different tissues of fresh water, Climbing perch (A. testudinus) using the comet assay. Highest damage was found at highest 
concentration. Among different tissues gill showed highest sensitivity. Nagarani et al. (2012) ${ }^{[61]}$ identified DNA damage in marine fish $T$. jarbua by comet assay technique when exposed to mercuric chloride $\left(\mathrm{HgCl}_{2}\right)$. DNA damage was studied in gill, kidney and blood tissue and the gill cells were found to be more sensitive to heavy metal exposure than kidney and blood cells. Abdel-Gawad et al. (2011) [1] evaluated DNA damage in fish and aquatic insects in the River Nile. Tail moment was used as a parameter for the assessment of DNA damage and high damage due to the pollutants present in the River Nile was observed. Further high damage was observed in the area from mixed point of agricultural drainage and waste water.

\section{Micronucleus assay in combination to comet assay}

One of the advantages of comet and MN assays is that both can be used for the simultaneous assessment of DNA damage in many tissues from the same animal, the comparison of their responses under identical treatment conditions. Thus, these techniques can be used in combination for screening genotoxic effect of chemicals and for investigating the implications of DNA damage and its recovery in the sentinel fish species.Micronucleus test and comet assay are found to be easy, sensitive, rapid and extensively used methods for mutagenicity and genotoxicity testing in various laboratory and field studies (Ali et al., 2009; Ateeq et al., 2002, 2005; Cavas and Ergene-Gzukara et al., 2005a; Jha, 2004; Pandey et al., 2006; Sharma et al., 2007; Talapatra et al., 2006; Nagpure et al., 2007; Nwani et al., 2010; Ventura Campo de et al., 2008;) Buschini et al. (2004) [16, 96, 30, 24, 62, 73, 81, 96]. evaluated the mutagenic effect of disinfectant added to the lake water for potabilization in fish $C$. carpio. Comet assay and micronucleus assay were performed on the circulating erythrocytes. Sodium hypochlorite, peracetic acid and chloride dioxide were the three disinfectants used in treating water continuously. Blood samples were taken before adding disinfectant, 3 hours and 10 or 20 days afterward. Sodium hypochlorite and chloride dioxide were the two disinfectants showing the genotoxicity. Russo et al. (2004) ${ }^{\text {[77] }}$ selected two natural environments for analyzing the biological damage (polluted water of Sarno River and Astroni natural reserve as negative control). Gambusia holbrooki was used as test organism and micronuclei (MN) test and single cell gel electrophoresis (the Comet assay) were used for environmental stress evaluation. Both the parameters showed high genotoxicity in the samples from the Sarno River as compared with Astroni. Matsumoto et al. (2006) ${ }^{[54]}$ used comet and micronucleus assay in erythrocytes of $O$. niloticus. Studied samples of water were taken from Catfish Brook in Franca, a city in the Brazilian state of $\mathrm{S}^{\sim}$ ao Paulo. The highest DNA damage was observed in the samples from the tanning region containing chromium effluent. Comet assay revealed the maximum damage from chromium containing tannery effluent site. Ali et al. (2009) found the genotoxicity of chlorpyrifos in fish $C$. punctatus. Lymphocyte and gill cells were used for the testing. Highest induction of $\mathrm{MN}$ was observed at $14^{\text {th }}$ day while highest DNA damage was

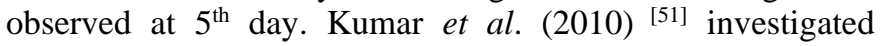
genotoxicity of malathion (pesticide) in kidney, gill and lymphocytes of $C$. punctatus using the micronucleus test and comet assay. A concentration dependent increase in DNA damage was observed up to three days followed by a nonlinear decrease with the duration of exposure. Comparison of DNA damage occurred among various tissues showed the sensitivity of gill tissue to malathion. Nwani et al. (2010) tested the mutagenic effect of carbosulfan (insecticide) in fish C. punctatus. Both the parameters ( $\mathrm{MN}$ and comet assay) were used for testing. Fish were exposed to three sublethal concentrations of carbosulfan $(67,134$ and 201 $\mu \mathrm{g} / \mathrm{l})$ for 96 hours. Highest damage was observed at 96 hours of exposure in erythrocytes and gill cells. Diekmann et al. (2004) [33] examined the genotoxic potential of 4 nitrous oxide in a complete life cycle of Zebrafish (D. rerio) by using the comet assay and micronucleus assay. Lower reproductivity and increased genotoxicity were observed. Ferraro et al. (2004) ${ }^{[35]}$ assessed the mutagenic effect of 2 months exposure to tributylin (TBT) and lead $(\mathrm{Pb})$ on Hoplias malabaricus. Comet assay, micronucleus assay and chromosomal aberration were used as genetic biomarkers. Blood cells were used for comet assay and results indicated genotoxicity with $\mathrm{Pb}$ but the results were not positive with TBT. On the other hand the micronucleus and chromosomal assay indicated the mutagenic effect of both TBT and PB. Caliani et al. (2009) ${ }^{[25]}$ assessed the potential genotoxicity of produced water (PW) containing residual hydrocarbon, trace elements, naturally occurring radioactive material and potential toxic treatment chemicals such as biocides, dispersants, detergents and scale inhibitors used in oil production to Mosquito fish (G. affinis) for 30 days. Genotoxicity was evaluated by the comet assay and micronucleus test. A positive correlation between MN and PAH metabolites was found. Nwani et al. (2011) [65] investigated the potential hazard associated with atrazine based herbicide on fish $C$. punctatus using the micronucleus assay and single cell gel electrophoresis. Gill tissue and erythrocytes were used for the analysis. Three sublethal concentrations $8.48,5.30$ and $4.24 \mathrm{mg} / \mathrm{l}$ for a period of $1,3,5$, $7,14,21,28$ and 35 days were used for the exposure. Highest MN frequency in blood cells was on the $7^{\text {th }}$ day with the highest concentration, while longest tail was observed on $5^{\text {th }}$ day followed by non-linear decline. Rocco et al. (2012) ${ }^{[76]}$ assessed the genotoxic effects of erythromycin and lincomycin and combination of these two antibiotics on the genome of zebra fish by using micronucleus assay on erythrocytes and the comet assay on erythrocytes and hepatocytes. It was found that treatment led to increase in DNA migration (tail moment) and significant increase in micronucleus frequency. Repair mechanism was also analyzed by removing genotoxic agent and it was found that only a few cells displaced the damaged cells. Faßbender and Braunbeck, (2013) ${ }^{[34]}$ performed a multigenerational study to assess the reproductive and the genotoxic effect of methyl methanesulfonate in Zebrafish after chronic exposure. Genotoxicity testing was done using comet and micronucleus assay. The significant genotoxic effect was observed in liver, gills and gonads while no detrimental effect on growth was seen. Palanikumar et al. (2013) ${ }^{[72]}$ found significant induction of $\mathrm{MN}$ and $\mathrm{BN}$ with the increasing concentration of naphthalene when compared to control and solvent control group. Maximum nuclear abnormality frequency was recorded for $1.24 \mu \mathrm{g} / \mathrm{l}$ of naphthalene. The DNA damage index was measured as percent comet tail in the gill and liver tissues of control and treatment groups. DNA damage increased with increase in concentration. Kumar et al. (2013) [50] conducted an experiment to assess the genotoxicity and oxidative stress of potassium dichromate in fish $C$. carpio. Genotoxicity was assessed in blood and gill tissue using comet and micronucleus assay and oxidative stress (OS) was estimated in liver, kidney and gill tissues. Both the tissues 
showed a concentration dependent increase in MN frequency and comet tail length. Tan et al. (2013) ${ }^{[95]}$ observed a significant induction of micronuclei and other nuclear abnormalities as well as olive tail moment and percent tail DNA in fish $C$. auratus after exposure with acrylamide. Mutagenic effect to 5, 10 and $20 \mathrm{mg} / \mathrm{l}$ acrylamide for a period of 96 hours was assessed using peripheral blood. Ali et al. (2014) ${ }^{[8]}$ used $C$. punctatus for study of genotoxicity and oxidative stress response caused by dimethoate (organophosphate insecticide). Concentration and time dependent increase in $\mathrm{MN}$ induction and DNA damage were found. 3 week exposure of dialkyl phthalate, bisphenol A, tetrabromodiphenyl ether (50 ppb of each) and nonylphenol $(30 \mathrm{ppb})$ as well as the mixture were given to fish $S$. maximus. Highest effect was observed in a mixture of sea oil and alkylated phenols. Bisphenol and tetrabromodiphenylether also showed the significant induction of $\mathrm{MN}$ and NA (Bolognesi et al., 2006) ${ }^{[22] .}$

Cavalcante et al. (2008) ${ }^{[27]}$ who tested blood and gill cells of fish and found high damage at 6 hours of exposure, but at 24 hours blood cells showed decreased damage and in contrast to this gill showed high damage at 24 hours. Similarly Banu et al. (2001) ${ }^{[19]}$ showed that monocrotophos treatment in fish, Tilapia mossambica lead to time dependent reduction in DNA damage. 24 and 48 hours of exposure show highest damage followed by a drop in the value up to 96 hours of exposure at all the concentrations and value almost return to the control value. Further Gulsoy et al. (2015) ${ }^{[43]}$ reported that when Zebra fish (D. rerio) were exposed to borax, the highest DNA damage was observed at 24 hours, followed by decrease at 48 and 72 hours and again increase in the value was observed at 96 hours, while treatment with boric acid induced highest effect at 96 hours of exposure. Ali and Kumar, (2008) [7, 9] reported that when fish $C$. punctatus were exposed to monocrotophos gill, liver and lymphocytes show highest damage at $4^{\text {th }}$ day followed by decline in value afterwards. Mohanty et al. (2011) ${ }^{[58]}$ found the highest damage in liver of fish $L$. rohita after treatment with organophosphate pesticide shows highest damage at 72 hours and then DNA damage get decreased at 96 hours when treated with. Ahmed et al. (2011) ${ }^{[4]}$ reported significant induction of DNA damage at 48 and 96 hours of exposure followed by a decline after 192 hours of exposure.

Gill cells were found to be more sensitive than lymphocytes, blood erythrocytes, kidney or liver cells by various researchers (Ateeq et al., 2005; Ali and Kumar, 2008; Ali et al., 2008, 2009; Nwani et al., 2010; Pandey et al., 2006; Sharma et al., 2007). On the other hand Akter et al. (2009) [16, $6,7,9,64,73,81]$ reported high apoptotic cells in liver tissue of $A$. testudineus when exposed to heavy metals. Likewise Kilemade et al. (2004) ${ }^{[48]}$ found a sensitivity of liver tissue over gill, blood and spleen in Juvenile turbot. The liver may also show high genotoxicity as lower molecular sulphate conjugates could favor their removal by kidney and gill (Vazquez-Duhalt et al., 2005) ${ }^{[95]}$. Uguz et al. (2006) [94] found time dependent accumulation of 4-NP in liver cells of fish Onchirynchus mykiss.

These studies suggested the usefulness of DNA damage assessment using comet assay in combination with micronucleus test to investigate the possible mechanism of genotoxicity in fish.

\section{Assessing DNA repair activity}

Another aspect studied in this review is paucity of knowledge concerning DNA repair capabilities. To enrich this scientific field such studies can be considered challenging. The knowledge of DNA repair in the tested species is important as it represents the first line of defense against genotoxicants. Guilherme et al. (2014) ${ }^{[41]}$ studied the genotoxic effect of Round up ${ }^{\circledR}$ and Garlon ${ }^{\circledR}$ in European eel (A. anguilla) and the extent of recovery was also studied after cessation of exposure and blood cells were found to be recovered more successfully. Marques et al. (2014) [53] evaluated the mechanism of genotoxicity induced by glyphosate based herbicide and repair in A. anguilla upon exposure and post exposure period. Exposure was given for 3 days and post exposure period was 1-14 days. It was found that the DNA integrity returned to control level after 1 day post exposure. Damage dropped to control value suggested the possibility of complete turnover of fish erythrocytes and other cells. The life span of erythrocytes in fish is from 1-3 months (Udroiu, 2006) ${ }^{[93]}$. Similar results were found by Bony et al., (2008) [23] in Trout in response to vineyard pesticide, in Carp and Bullheads (Pandrangi et al., 1995) ${ }^{[74]}$ and in Chub (Devaux et al., 1998) ${ }^{[32]}$. Similar results were also found by Mohanty et al. (2011) ${ }^{[58]}$ in fish $L$. rohita which were exposed to organophosate pesticide. They observed the DNA break reduction in liver tissue after 3 hours and the fish returned to control levels damage in 24 hours. This may be due to DNA repair system which may lead to elimination of DNA lesions. Abdel-Tawwab, (2012) ${ }^{[2]}$ observed that fish gradually recover close to the control values after 3 to 4 weeks of recovery in the Nile tilapia after exposure to commercial petroleum fuels. Sharma and Chadha, (2017) ${ }^{[82]}$ observed significant reduction in DNA damage after 30 days recovery period when fish $C$. punctatus exposed with 4-nonylphenol for 90 days sub chronic exposure.

\section{Conclusion}

As evident from the review the toxicological relevance of micronucleus assay, polychromatic erythrocyte frequency and comet assay is well defined as the parameters are simple to score, accurate and applicable to different cells. $\mathrm{MN}$ and comet assay can be used to identify potential biomarkers that allow the identification of early genotoxic damage in a simple and effective manner and proves to be effective tools for genotoxicity evaluation. Finally the studies dealing with repair of DNA damage can be used to illustrate the repair and cellular turnover.

\section{References}

1. Abdel-Gawad CK, Nadia M, Hassanein MA, Bassem SM. Evaluation of DNA damage in fish and aquatic insects induced by environmental pollutants in River Nile. World Applied Sciences Journal 2011;14(7):10851090.

2. Abdel-Tawwab M. Chronic effect after acute exposure to commercial petroleum fuels on physiological status of Nile tilapia, Oreochromis niloticus (L.) International Aquatic Research 2012;4:11.

3. Abdul-Farah M, Ateeq B, Ali MN, Ahmad W. Evaluation of genotoxicity of PCP and 2,4-dichlorophenoxyacetic acid by micronucleus test in freshwater fish Channa punctatus (Bloch). Ecotoxicology and Environmental Safety 2003;54:25-29.

4. Ahmed K, Al-Mamun HM, Hossain A, Arif M, Parvin E, Khan MSA, et al. Assessing the genotoxic potentials of arsenic in tilapia (Oreochromis mossambicus) using 
alkaline comet assay and micronucleus test. Chemosphere 2011;84:143-149.

5. Ahmed MK, Parvin E, Arif M, Akter MS, Khan MS, Islama MM. Measurements of genotoxic potential of cadmium in different tissues of fresh water climbing perch Anabas testudineus (Bloch), using the comet assay. Environmental Toxicology and Pharmacology 2012;30:80-84.

6. Akter MS, Ahmed MK, Akhand AA, Ahsan N, Islam MM, Khan MS. Arsenic and mercury induce death of Anabas testudineus (Bloch) involving fragmentation of chromosomal DNA. Terrestrial and Aquatic Environmental Toxicology 2009;3(1):42-47.

7. Ali D, Kumar S. Long-term genotoxic effect of monocrotophos in different tissues of freshwater fish Channa punctatus (Bloch) using alkaline single cell gel electrophoresis. Science of the Total Environment 2008;405:345-350.

8. Ali D, Kumar PG, Kumar S, Ahmed M. Evaluation of genotoxic and oxidative stress response to dimethoate in freshwater fish, Channa punctatus (Bloch). Chemical Speciation and Bioavailability 2014;26(2):111-118.

9. Ali D, Nagpure NS, Kumar S, Kumar R, Kushwaha B. Genotoxicity assessment of acute exposure of chlorpyriphos to fresh water fish, Channa punctatus (Bloch) using the micronucleus assay and alkaline singlecell gel electrophoresis. Chemosphere 2008;71:18231831.

10. Ali D, Nagpure NS, Kumar S, Kumar R, Kushwaha B, Lakra WS. Assessment of genotoxic and mutagenic effects of chlorpyriphos in fresh water fish Channa punctatus (Bloch) using micronucleus assay and alkaline single-cell gel electrophoresis. Food and Chemical Toxicology 2009;47:650-656.

11. Andrade VM, Freitas TRO, Silva J. Comet assay using mullet (Mugil sp.) and sea catfish (Netuma sp.) erythrocytes for the detection of genotoxic pollutants in aquatic environment. Mutation Research 2004;560:57-67.

12. Ansari RA, Kaur M, Ahmad F, Rahman S, Rashid H, Islam $\mathrm{F}$, et al. Genotoxic and oxidative stressinducing effects of deltamethrin in the erythrocytes of a freshwater biomarker fish species, Channa punctata (Bloch). Environmental Toxicology 2009;24(5):429-436.

13. Ansari RA, Rahman S, Kaur M, Anjum S, Raisuddin S. In vivo cytogenetic and oxidative stressinducing effects of cypermethrin in freshwater fish, Channa punctata Bloch. Ecotoxicology and Environmental Safety 2011;74:150-156.

14. Arslan OC, Parlak H, Katalay S, Boyacioglu M, Karaaslan MA, Guner H. Detecting micronuclei frequency monitoring pollution of Izmir Bay (Western Turkey). Environmental Monitoring and Assessment 2010;165:55-66.

15. Ateeq B, Abul-Farah M, Ali MN, Ahmad W. Induction of micronuclei and erythrocyte alterations in the catfish Clarias batrachus by 2,4- dichlorophenoxyacetic acid and butachlor. Mutation Research 2002;518:135-144.

16. Ateeq B, Farah MA, Ahmad W. Detection of DNA damage by alkaline single cell gel electrophoresis in 2, 4dichlorophenoxyacetic-acid- and butachlor-exposed erythrocytes of Clarias batrachus. Ecotoxicology and Environmental Safety 2005;62:348-354.

17. Ayoola SO, Bassey BO, Alimba CG, Ajani, E. K. (2012). Textile effluent induced genotoxic effects and oxidative stress in Clarias gariepinus. Pakistan Journal of Biology and Science 2005;15(17):804-812.

18. Ayllon F, Garcia-Vazquez E. Induction of micronuclei and other nuclear abnormalities in European minnow Phoxinus phoxinus and mollie Poecilia latipinna: an assessment of the fish micronucleus test. Mutation Research 2000;467:177-186.

19. Banu BS, Danadevi K, Rahman MF, Ahuja YR, Kaiser J. Genotoxic effect of monocrotophos to sentinel species using comet assay. Food and Chemical Toxicology 2001;39:361-366.

20. Balpaeme K, Delbeke K, Zhu L, Kirsch-Folders M. Cytogenetic studies of PCB77 on brown trout (Salmo trutto fario) using the micronucleus test and the alkaline comet assay. Mutagenesis 1996;11:485-492.

21. Baršiene J, Dedonyte V, Rybakovas A, Andreikenaite L, Andersen OK. Investigation of micronuclei and other nuclear abnormalities in peripheral blood and kidney of marine fish treated with crude oil. Aquatic Toxicology 2006;78:S99-S104.

22. Bolognesi C, Perrone E, Roggieri P, Pampanin DM, Sciutto A. Assessment of micronuclei induction in peripheral erythrocytes of fish exposed to xenobiotics under controlled conditions. Aquatic Toxicology 2006;78:S93-S98.

23. Bony S, Gillet C, Bouchez A, Margoum C, Devaux A. Genotoxic pressure of vineyard pesticides in fish: Field and mesocosm surveys. Aquatic Toxicology 2008;89:197-203.

24. Buschini A, Martino A, Gustavino B, Monfrinotti M, Poli $\mathrm{P}$, Rossi C, et al. Comet assay and micronucleus test in circulating erythrocytes of Cyprinus carpio specimens exposed in situ to lake waters treated with disinfectants for potabilization. Mutation Research 2004;557:119-129.

25. Caliani I, Porcelloni S, Mori G, Frenzilli G, Ferraro M, Marsili L, et al. Genotoxic effects of produced waters in mosquito fish (Gambusia affinis). Ecotoxicology 2009;18(1):75-80.

26. Candioti JV, Natale GS, Soloneski S, Ronco AE. Sublethal and lethal effects on Rhinella Arenarum (Anura, Bufonidae) tadpoles exerted by the pirimicarbcontaining technical formulation insecticide Aficida ${ }^{\circledR}$. Chemosphere 2010;78:249-255.

27. Cavalcante M, Martinez R, Sofia S. Genotoxic effects of Roundup on the fish Prochilodus lineatus. Mutation Research 2008;655(1-2):41-46.

28. Çavas T, Ergene-Gözükara S. Evaluation of the genotoxic potential of lambda-cyhalothrin using nuclear and nucleolar biomarkers on fish cells. Mutation Research 2003a;534:93-99.

29. Çavaş T, Ergene-Gözükara S. Micronucleus test in fish cells: A bioassay for in situ monitoring of genotoxic pollution in the marine environment. Environmental and Molecular Mutagenesis 2005a;46(1):64-70.

30. Cavas T, Garanko NN, Arkhipchuk VV. Induction of micronuclei and binuclei in blood, gill and liver cells of fishes sub chronically exposed to cadmium chloride and copper sulphate. Food and Chemical Toxicology 2005;43(4):569-574.

31. Choudhary J, Jha A, Jha AM. Cytogenetic effect of Chromium trioxide in an air breathing teleost Channa punctatus (Bloch). International Journal of Pharma and Bio Sciences 2012;2(1):246-253. 
32. Devaux A, Flammarion P, Bernardon V, Garric J, Monod G. Monitoring of the chemical pollution of the River Rhône through the measurement of DNA damage and cytochrome P4501A induction in chub (Leuciscus cephalus). Marine Environmental Research 1998;46:257262.

33. Diekmann M, Waldmann P, Schnurstein A, Grummt T, Braunbeck T, Nagel R. On the relevance of genotoxicity for fish populations II: genotoxic effects in zebrafish (Danio rerio) exposed to 4-nitroquinoline-1-oxide in a complete life-cycle test. Aquatic Toxicology 2004;68:2737.

34. Faßbender C, Braunbeck T. Reproductive and genotoxic effects in zebrafish after chronic exposure to methyl methanesulfonate in a multigeneration study. Ecotoxicology 2013;22(5):825-837.

35. Ferraro MVM, Fenocchio AS, Mantovani M, Ribeiro COS, Cestari MM. Mutagenic effects of tributyltin and inorganic lead $(\mathrm{Pb}$ II) on the fish $H$. malabaricus as evaluated using the comet assay and the piscine micronucleus and chromosome aberration tests. Genetics and Molecular Biology 2004;27(1):103-107.

36. Frenzilli G, Scarcelli V, Del Barga I, Nigro M, Forlin L, Bolognesi $\mathrm{C}$, et al. DNA damage in eelpout (Zoarces viviparus) from $\mathrm{G}$ “oteborg harbour. Mutation Research 2004;552:187-195.

37. Galindo TPS, Rosário IR, Silva EM. Micronucleus test in frillfin goby Bathygobius soporator (Valenciennes, 1873) from tide pools of Salvador City, Brazil. Brazil Journal of Aquatic Science Technology 2014;18(1):19-24.

38. Garg R, Gupta S, Maru GB. Dietary curcumin modulates transcriptional regulators of phase I and phase II enzymes in benzo [a] pyrene-treated mechanism of its antiinitiating action. Carcinogenesis 2008;29:1022-1032.

39. Grisolia CK, Starling FLRM. Micronuclei monitoring of fishes from Lake Paranoá, under influence of sewage treatment plant discharges. Mutation Research 2001;491:39-44.

40. Grisolia CK. A comparison between mouse and fish micronucleus test using cyclophosphamide, mitomycin C and various pesticides. Mutation Research 2002;518:145150 .

41. Guilherme S, Santos MA, Gaivão I, Pacheco M. Are DNA-damaging effects induced by herbicide formulations (Roundup®and Garlon $®$ ) in fish transient and reversible upon cessation of exposure? Aquatic Toxicology 2014;155:213-221.

42. Guilherme S, Santos MA, Barroso C, Gaivão I, Pacheco M. Differential genotoxicity of Roundup ${ }^{\circledR}$ formulation and its constituents in blood cells of fish (Anguilla anguilla): Considerations on chemical interactions and DNA damaging mechanisms. Ecotoxicology 2012;21(5):1381-1390.

43. Gülsoy N, Yavaş C, Mutlu Ö. Genotoxic effects of boric acid and borax in zebrafish, Danio rerio using alkaline comet assay. Experimental and Clinical Sciences International Online Journal for Advances in Science 2015;14:890-899.

44. Ismail M, Khan QM, Ali R, Ali T, Mobeen A. Genotoxicity of chlorpyrifos in freshwater fish Labeo rohita using Alkaline Single-Cell Gel Electrophoresis (Comet) assay. Drug and Chemical Toxicology 2014;37(4):466-471.

45. Javed M, Usmani N. Toxic Effects of Heavy Metals $(\mathrm{Cu}$,
$\mathrm{Ni}, \mathrm{Fe}, \mathrm{Co}, \mathrm{Mn}, \mathrm{Cr}, \mathrm{Zn}$ ) to the Haematology of Mastacembelus armatus Thriving in Harduaganj Reservoir, Aligarh, India. Global Journal of Medical Research 2015;12(8):59-64.

46. Jerbi MA, Ouanesb Z, Besbesc R, Achoura L, Kacema A. Single and combined genotoxic and cytotoxic effects of two xenobiotics widely used in intensive aquaculture. Mutation Research 2011;724:22-27.

47. Kaur H, Kalotra R, Walia GK, Handa D. Genotoxicity in a freshwater fish, Cirrhinus mrigala exposed to dyeing industry effluent by using micronucleus test. International Journal of Recent Scientific Research 2013;4(8):12101213.

48. Kilemade MF, Hartl MGJ, Sheehan D, Mothersill C, Van Pelt FNAM, O' Halloran J, et al. Genotoxicity of field collected inter-tidal sediments from Cork Harbor, Ireland, to juvenile trubot (Scophthalmus maximus L.) as measured by the comet assay. Environmental and Molecular Mutagenesis 2004;44:56-64.

49. Koca YB, Koca S, Yıldız Ş, Gürcu B, Osanç E, Tunçbaş $\mathrm{O}$, et al. Investigation of histopathological and cytogenetic effects on Lepomis gibbosus (Pisces: Perciformes) in the Çine stream (Aydın/Turkey) with determination of water pollution. Environmental Toxicology 2005;20(6):560-571.

50. Kumar A, Kesari VP, Khan PK. Fish micronucleus assay to assess genotoxic potential of arsenic at its guideline exposure in aquatic environment. Biometals 2013;26:337-346.

51. Kumar R, Nagpure NS, Kushwaha B, Srivastava SK, Lakra WS. Investigation of the genotoxicity of Malathion to freshwater teleost fish Channa punctatus (Bloch) using the micronucleus test and comet assay. Archives of Environmental Contamination and Toxicology 2010;58:123-130.

52. Lasheen MR, Abdel-Gawad FK, Alaneny AA, Elbary HMHA. Fish as bio indicators in aquatic environmental pollution assessment: A case study in Abu-Rawash Area, Egypt. World Applied Sciences Journal 2012;19(2):265275.

53. Marques A, Guilherme S, Gaivao I, Santo MA, Pacheco M. Progression of DNA damage induced by a glyphosate-based herbicide in fish (Anguilla anguilla) upon exposure and post exposure period. Insight into the mechanism of genotoxicity and DNA repair. Comaprative Biochemistry and Physiology part C: Toxicology and Pharmacology 2014;166:126-133.

54. Matsumoto ST, Mantovani MS, Malaguttii MIA, Dias AL, Fonseca IC, Marin-Morales MA. Genotoxicity and mutagenicity of water contaminated with tannery effluents as evaluated by the micronucleus test and comet assay using the fish Oreochromis niloticus and chromosome aberrations in onion root-tips. Genetics and Molecular Biology 2006;29(1):148-158.

55. Meier JR, Chang LW, Franson SE, Daniel FB, Toth GP, Lazorchak J, Wernsing PA. Assessment of genetic damage indicators in fish in laboratory, mesocosm and watershed studies. Society of Environmental Toxicology and Chemistry 2002, 18-22.

56. Melo KM, Alves IR, Pieczarka JC, David JAO, Nagamachi CY, Grisolia CK. Profile of micronucleus frequencies and nuclear abnormalities in different species of electric fishes (Gymnotiformes) from the Eastern Amazon. Genetics and Molecular Biology 
2013;36(3):425-429.

57. Mitchelmore CL, Chipman JK. DNA strand breakage in aquatic organisms and the potential value of the comet assay in environmental monitoring. Mutation Research 1998;399:135-147.

58. Mohanty G, Mohanty J, Nayak AK, Mohanty S, Dutta SK. Application of comet assay in the study of DNA damage and recovery in rohu (Labeo rohita) fingerlings after an exposure to phorate, an organophosphate pesticide. Ecotoxicology 2011;20:283-292.

59. Muranli FDG, Guner U. Induction of micronuclei and nuclear abnormalities in erythrocytes of mosquito fish (Gambusia affinis) following exposure to the pyrethroid insecticide lamda- cyhalothrin. Mutation Research 2011;726:104-108.

60. Nagarani N, Devi VJ, Devi CA. Genotoxicity assessment of mercuric chloride in marine fish Therapon jarbua. Environmental Asia 2009;2:50-54.

61. Nagarani N, Devi VJ, Devi CA, Kumaraguru AK. Identification of DNA damage in marine fish Therapo jarbua by comet assay technique. Journal of Environmental Biology 2012;33(4):699-703.

62. Nagpure NS, Kumar R, Kushwaha B, Singh PJ, Sirivastava SK, Lakra WS. Genotoxicity assessment in fishes; A Practical Approach. NBFGR, Lucknow, India 2007, 126.

63. Nan P, Yan S, Li L, Chen J, Du Q, Chang Z. Toxicity effect of dichlorvos on loach (Misgurnus anguillicaudatus) assessed by micronucleus test, hepatase activity analysis and comet assay. Toxicology and Industrial Health 2014;31(6):566-575.

64. Nwani CD, Lakra WS, Nagpure NS, Kumar R, Kushwaha B, Srivastava SK. Mutagenic and genotoxic effects of carbosulfan in freshwater fish Channa punctatus (Bloch) using micronucleus assay and alkaline single-cell gel. Food and Chemical Toxicology 2010;48:202-208.

65. Nwani CD, Nagpure NS, Kumar R, Kushwaha B, Lakra WS. DNA damage and oxidative stress modulatory effects of glyphosate-based herbicide in freshwater fish, Channa punctatus. Environmental Toxicology and Pharmacology 2013;36(2):539-547.

66. Nwani CD, Nagpure NS, Kumar R, Kushwaha B, Kumar $\mathrm{P}$, Lakra WS. Mutagenic and genotoxic assessment of atrazine-based herbicide to freshwater fish Channa punctatus (Bloch) using micronucleus test and single cell gel electrophoresis. Environmental Toxicology and Pharmacology 2011;31(2):314-322.

67. Olive P, Banath JP. The Conet assay: a method to measure DNA damage in individual cells. Nature protocols 2006;1(1):23-29.

68. Omar WA, Zaghloul KH, Abdel-Khalek AA, Abo-Hegab S. Genotoxic effects of metal pollution in two fish species, Oreochromis niloticus and Mugil cephalus, from highly degraded aquatic habitats. Mutation Research-Genetic Toxicology and Environmental Mutagenesis 2012;746(1):7-14.

69. Osman AGM. Genotoxicity tests and their contributions in aquatic environmental research. Journal of Environmental protection 2014;5:1391-1399.

70. Osterauer R, Faßbender C, Braunbeck T, Köhler HR. Genotoxicity of platinum in embryos of zebrafish (Danio rerio) and ramshorn snail (Marisa cornuarietis). Science of the Total Environment 2011;409:2114-2119.
71. Pacheco M, Santos MA. Biotransformation, genotoxic and histopathological effects of environmental contaminants in European eel, Anguilla anguilla. Ecotoxicology and Environmental Safety 2002;53:331347.

72. Palanikumar L, Kumaraguru AK, Ramakritinan CM. Biochemical and genotoxic response of naphthalene to fingerlings of milkfish Chanos chanos. Ecotoxicology 2013;22:1111-1122.

73. Pandey AK, Nagpure NS, Trivedi SP, Kumar R, Kushwaha B. Profenofos induced DNA damage in freshwater fish, Channa punctatus (Bloch) using alkaline single cell gel electrophoresis. Mutation Research Genetic Toxicology and Environmental Mutagenesis 2011;726(2):209-214.

74. Pandrangi R, Petras M, Ralph S, Vrzoc M. Alkaline single cell gel (Comet) assay and genotoxicity monitoring using bullheads and carp. Environmental and Molecular Mutagenesis 1995;26:345-356.

75. Randalli DJ, Farrell AP. Fish Physiology: The Cardiovascular System, William Steward Hoar. Academiz Press 1992;12:9.

76. Rocco L, Peluso C, Stingo V. Micronucleus test and comet assay for the evaluation of zebrafish genomic damage induced by erythromycin and lincomycin. Environmental Toxicology 2012;27(10):598-604.

77. Russo C, Rocco L, Morescalchi MA, Stingo V. Assessment of environmental stress by the micronucleus test and the Comet assay on the genome of teleost populations from two natural environments. Ecotoxicology and Environmental Safety 2004;57(2):168-174.

78. Schroeder HA, et al. Essential trace metals in man. A study in homeostasis: Manganese. J Chron Dis 1966;19:545-571.

79. Simoniello MF, Gigena F, Poletta G, Loteste A, Kleinsorge E, Campana M, et al. Alkaline Comet Assay for Genotoxic Effect Detection in Neotropical Fish Prochilodus lineatus (Pisces, Curimatidae). Bulletin of Environmental Contamination and Toxicology 2009;83:155-158.

80. Schmid W. The micronucleus test for cytogenetic analysis. In Hollaender, A. (ed.) Chemical mutagenesis. Plenum Press, New York, NY 1976, 31-53.

81. Sharma S, Nagpure NS, Kumar R, Pandey S, Srivastava SK, Singh PJ et al. Studies on the genotoxicity of endosulfan in different tissues of fresh water fish Mystus vittatus using the comet assay. Archives of Enviromental Contamination and Toxicology 2007;53:617-623.

82. Sharma M, Chadha P. Widely used non ionic surfactant 4-nonylphenol: showing genotoxic effect in various tissues of Channa punctatus. Environmental Science and Pollution Research 2017;Q24(12), 11331-11339.

83. Sharma M, Chadha P. 4-Nonylphenol induced DNA damage and repair in fish, Channa punctatus after sub chronic exposure. Drug and Chemical Toxicology 2016;40(3):320-325.

84. Sharma M, Chadha P, Sharma S. Acute and sub- chronic exposure of 4-nonylphenol to freshwater fish, Channa punctatus to evaluate its cytotoxicity. Biochemical and Cellular Archives 2014;14(2):363-367.

85. Srivastva P, Singh A. Evidence of micronuclei in fish blood as a biomarker of genotoxicity due to surface runoff agricultural fungicide (Propiconazole). Journal of 
toxicology and environmental health Sciences 2015;71(1):4-8.

86. Sunjog K, Kolarević S, Héberger K, Gačić Z, KneževićVukčević J, Vuković-Gačić B, et al. Comparison of comet assay parameters for estimation of genotoxicity by sum of ranking differences. Analytical and Bioanalytical Chemistry 2013;405:4879-4885.

87. Suzuki Y, Nagae Y, Li J, Sabaka H, Mazowa K, Takahashi A, Shimuzu H. The micronucleus test and erythropoiesis: effects of erythropoietin and a mutagen on the ratio of polychromatic to normochromatic erythrocytes (P/N ratio). Mutagenesis 1989;4:420-424.

88. Talapatra SN, Banerjee SK. Detection of micronucleus and abnormal nucleus in erythrocytes from the gill and kidney of Labeo bata cultivated in sewage-fed fish farms. Food and Chemical Toxicology 2007;45:210-215.

89. Talapatra SN, Banerjee P, Mukhopadhyay A. Dose- and time-dependent micronucleus inductionin peripheral erythrocytes of catfish, Heteropneustes fossilis (Bloch) by zinc. International Letters of Natural Sciences 2014;4:36-43.

90. Tan D, Li L, Wang S, Wei B, Zhang X, Sun B, et al. The cytogenetic effects of acrylamide on Carassius auratus periperial blood cells. Food and Chemical Toxicology 2013;62:318-322.

91. Tanaka JN, Grizzle JM. Effects of nonylphenol on the gonadal differentiation of the hermaphroditic fish, Rivulus marmoratus. Aquatic Toxicology 2002;57(3):117-122.

92. Ternjej I, Mihaljevic' Z, Stankovic I, Kerovec M, Sipos L, Z $Z^{\swarrow}$ eljez ic $^{\prime}$ D, Kopjar N. Estimation of DNA integrity in blood cells of Eastern Mosquitofish (Gambusia holbrooki) inhabiting an aluminium-polluted water environment: an alkaline comet assay study. Archives of Environmental Contamination and Toxicology 2010;59:182-193.

93. Udroiu I. The micronucleus test in piscine erythrocytes. Aquatic Toxicology 2006;79:201-204.

94. Uguz C, Iscan M, Togan I. Developmental genetics and physiology of sex differentiation in vertebrates. Environmental Toxicology and Pharmacology 2003;14(1):9-16.

95. Vazquez-Duhalt R, Marquez-Rocha F, Ponce E, Licea AF, Vaiana MT. Nonylphenol and integrated vision of a pollutant. Applied Ecology and Environmental Research 2005;4:1-25.

96. Ventura BC, Angelis DF, Marin-Morales MA. Mutagenic and genotoxic effects of the atrazine herbicide in Oreochromis niloticus (Peciformes, Cichlidae) detected by micronuclei test and the comet assay. Pesticide Biochemistry and Physiology 2008;90:42-51.

97. Winter MJ, Ellis LCJ, Hutchinson TH. Formation of micronuclei in erythrocytes of the fathead minnow (Pimephales promelas) after acute treatment with mitomycin C or cyclophosphamide. Mutation Research Genetic Toxicology and Environmental Mutagenesis 2007;629(2):89-99.

98. Woo S, Kim S, Yum S, Yim UH, Lee TK. Comet assay for the detection of genotoxicity in blood cells of flounder (Paralichthys olivaceus) exposed to sediments and polycyclic aromatic hydrocarbons. Marine Pollution Bulletin 2006;52:1768-1775.

99. Yadav KK, Trivedi SP. Sublethal exposure of heavy metals induces micronuclei in fish, Channa punctata. 